\title{
BEDNANICS GÁBOR
}

\section{Encomium philogiae Egy elfeledett életmú kihült nyomai}

Martianus Capella egyetlen fennmaradt művében olyan példaértékű viszonyt állított a középkori müvészetszemlélet elé, amely azóta is sokat vitatott, de jó esetben szem előtt tartandónak bizonyult. A mű meghatározta az akadémiai stúdiumokat a kora középkorban, és a benne felvonultatott hét szabad művészet allegorikus alakjai beszámolóikban rendre úgy írják le a tevékenységüket, mint amely ugyan az érzékiből táplálkozik, de nem földi dolgokra irányul, hanem szellemiekre. A Philologia által elfogadott Mercurius szolgálói így isteni védelemben részesültek, az általuk gondozott diszciplínák pedig évszázadokig mércéül szolgáltak a tudás elnyerésének folyamatában. A De nuptiis Philologiae et Mercurii újkori üzenetét inkább abban lehet megragadni, amire Jauss korszakos művének bevezetőjében utal, nevezetesen esztétikai tapasztalat és irodalmi hermeneutika kapcsolatában. ${ }^{1}$ A mitikus történet utalásszerkezete ugyanis felhívja a figyelmet arra, hogy a filológiai megismerés objektivitása esztétikai szövegviszony nélkül értelmetlen, ${ }^{2}$ de arra is, hogy az interpretáció a szövegtapasztalat közvetítette bizonyosság nélkül esendő. A filológiai tudás mindig bizonyosságot keres, de közben ki van téve a szétszálazó műveletekben rejlő kiszámíthatatlanságnak. Bár megismerésként tekint magára, a megértés (merkúri) teljesítménye irányítja. Ahogy Apolló az ékesszólás istenének Philologiát ajánlja nőül, úgy nem árt szem előtt tartani, hogy a leány is kap valamit e frigyből. E kölcsönösség a szöveg fogalmában teljesedett ki, melyre egyaránt támaszkodik az irodalmi elemzés gyakorlata és a textológia eljárásmódja is. ${ }^{3} \mathrm{Ez}$ az évszázad azonban maga is többféle filológiai alapvetésnek adott teret. Mindezt leginkább egy olyan klasszika-filológus példáján keresztül lehet szemléltetni, aki maga is áldozott az antik szövegek edíciójának oltárán, miközben kegyvesztettje is lett ennek a vallásnak, mikor filozófusként szembeszállt a megszokott elvárásokkal a kulturális kontextus átértelmezésével.

1 Hans Robert Jauss, Ästetische Erfahrung und literarische Hermeneutik (Frankfurt: Suhrkamp, 1991), 10.

2 Heinz SCHLAFFER, „Filológiai megismerés”, in DéRI Balázs és mások szerk., Metafilológia 1. (Budapest: Ráció, 2011), 575.

3 Vö. Bernard CerquiglinI, „A variáns dicsérete”, in DéRI Balázs és mások szerk., Metafilológia 1.

(Budapest: Ráció, 2011), 232. 
Nietzsche az 1871-es nyári félévben tartott előadásán (mely A klasszika-filológia enciklopédiája címet viselte) a filológus hagyományos feladatai mellett fellelkesült szólamot is intézett - legalábbis az előadásvázlatból következtehetünk erre - hallgatóihoz, melyben a görögök zsenijéről, naivitásáról (azaz egyszerűségükről és mélységükről), ezek megismeréséről és követéséről szól, miáltal voltaképpen a korszak közhelyeit segítségül véve vázolja fel az egész stúdium alapjait. Ám szükségesnek ítélte zárszóként az egész tevékenység értelmét felmutatni, ami ha nem is egyedülálló jelenség, de mindenképpen felhívja a figyelmet a tudományág magától értetődőségének tarthatatlanságára. Azért szükséges hangsúlyozni ezt, mert - hozzávéve $A$ tragédia születésének filológusokat ócsárló részletét, mely ebből az időszakból való - a filológia tudomány volta ebben az időben nem volt olyannyira kérdéses, mint manapság: a filológiát (ókortudományt) alaptudománynak tekintették, mely jelentős állami támogatásban részesült, konkurens csoportok filológus-vezéralakok köré gyülekeztek, s nem volt semmi kivetnivaló abban, hogy legfőbb céljuk a szövegek gondozása, s ennek lehetséges következményeként az emberek jobbá tétele is volt. ${ }^{4}$ Nietzsche ebben a humánideológiában nem hitt, a filológia ebből fakadó öncélúsága pedig magyarázatért kiáltott. Először jobbára a filológia tudomány voltát kívánta megragadni, azzal a hármas kritériummal, melyet szintén eme előadástervezetben olvashatunk: 1) filozófiai előkészületek, 2) helyes módszer, illetve 3) általános tájékozódás. ${ }^{5}$ Az igény, hogy a filológiai tevékenységet megalapozzuk, már a filozófiából érkezik: Nietzsche székfoglaló előadásának sokat idézett mondata, a Seneca-féle kijelentés megfordítása („Philosophia facta est quae philologia fuit”) a filozófiának olyan jellemzőit emeli ki, amelyek kívülről lépnek a filológia legitimnek tartott vizsgálódásai körébe, s amelyek ezzel a belépéssel megfosztják a filológiát fundamentális értelmező szerepétől. Ha eddig a tudományos tevékenység szintjén föl sem merült, hogy a filológia ne lenne tudomány, ${ }^{6}$ most abban az összefüggésben - amelybe jobbára csak a századfordulón kerül -, hogy ti. pozitív tudomány-e, valóban égető kérdéssé válik. Talán nem járunk messze az igazságtól, ha Nietzsche dilemmáit ennek a pozitivitásnak a függvényében szemléljük, s a filozófia vs. filológia szembehelyezést az önlegitimáció kudarcából származtatjuk.

A legitimációs törekvés megjelenése a későbbi Nietzsche-szövegekben egyre nagyobb szerepet játszik. Nem kívánom sem alul-, sem pedig túlértékelni $A$ tragédia születése körüli vitát, emiatt ennek részleteibe nem bocsátkozom. Talán annak

4 Vö. Glenn W. Most, „Friedrich Nietzsche zwischen Philosophie und Philologie”, Ruperto Carola. Forschungsmagazin der Universität Heidelberg 2 (1994), 12-17., 24.

5 Friedrich Nietzsche, Kritische Gesammelte Werke II., szerk. Fritz Bornmann - Mario Carpitella (Berlin - New York: Walter de Gruyter, 1993), 3., 388.

6 Még Boeckh is a filológia alaptudományként való aposztrofálásával, a többi résztudománytól (nyelvészet, irodalomtörténet, történelem, sőt ókortudomány) negatív elkülönítésével próbálja megragadni a filológia lényegét, melyet végül a már ismert megismerésében talál fel. August BoECKH, Enzyklopädie und Methodologie der philologischen Wissenschaften (Leipzig: Teubner, 1877), 3-33. 
megfontolása, hogy a bírálatok inkább intézményes-diszkurzív viszonyokat sejtetnek, mintsem szakmait, azt jól szemlélteti, hogy (nem először és nem utoljára) egy ifjú (Nietzschénél is fiatalabb) kutatót szabadítanak rá a bázeli filológusra, aki jól láthatóan megfelelt a feltételezett igényeknek, és elég durva kritikát közölt a híres könyvről. Annyi azonban bizonyos, hogy Nietzsche ekkor már korszerútlen filológussá lett, aki napi penzumait (előadások és szemináriumok megtartását) a hagyományos keretek között teljesíti, ámde egyre szélesebb tapasztalati kör legitimációs kérdéseivel foglalkozik. A mindegyre szaporodó írások a német nevelési intézmények jövőjéről, a görög embertelenségnek a humanitáseszmény torzító képével való szembeállításáról, a preszókratikus filozófusoknak a Szókratész utáni gondolkodáshoz mért felértékeléséről vagy a hazug igazság leleplezéséről ezt a táguló perspektívát mutatják fel, ahol a filológia témája nem lesz központivá, de megközelítésmódjai tovább működnek.

A filológia és filozófia közötti folytonosság (túl azon, hogy Nietzsche elég sokáig filozófusnak is korszerütlen) mibenléte a filológus helyzetének (keletkezésének, céljainak, hasznának) tisztázásában érthető leginkább tetten. Az a néhány töredék, amely a Mi filológusok címen tervezett ötödik korszerütlen elmélkedés lett volna, e kép árnyalásához nyújt segítséget. A töredékekben, feljegyzésekben főként az új, az eddigitől teljességgel eltérő, „valódi” görögségképet, illetve a nevelés, szűkebben: a filológus nevelésének kérdését járja körül Nietzsche. A filológusok nevelését alapvetően elhibázottnak tartja. A fiatal filológus nem rendelkezik kellő előismerettel ahhoz, hogy dönthessen arról, filológus lesz-e vagy sem. Indítékai pusztán az utánzás, a kényelemszeretet (mivel azt folytatja, amit az iskolában űzött), és hogy egyre inkább a kenyérkereset szándéka mozgatja. ${ }^{7}$ Az elhibázott filológusi pálya pedig összefonódik azzal a jelenséggel, hogy hamis hozzáállásból (hibás görögségképből) kiindulva a filológus voltaképpen hamis viszonyt létesít a régiséggel, amit megfordítva is előadhatunk: a hibás attitűd (menekülés a görög ideálhoz) formálta meg a hamis görögségképet. A görögök és kutatóik között Nietzsche áthidalhatatlan szakadékot felételez, melyben egyetlen tudományos módszer vezetne sikerre: ha a filológus tudatosítaná előfeltevéseit és az azokat formáló erőket és körülményeket. „Három dolgot kell a filológusnak kell megértenie ahhoz, hogy ártatlanságát bebizonyítsa: az ókort, a jelent és önmagát: vétkes akkor, ha vagy az ókort, vagy a jelent, vagy önmagát nem érti." ${ }^{8}$ A megértés alapfeltételként rögzítése viszont nem annak a filológiának a feladata, amely hermeneutikában és kritikában gondolkodik. ${ }^{9}$ Sokkal

\footnotetext{
7 Friedrich Nietzsche, Ifjúkori görög tárgyú írások, ford. Molnár Anna, (Budapest: Helikon, 1988), 152-153.

8 Uo., 183.

9 Így tette ezt Nietzsche is a klasszikafilológia-előadásában a kritikát az áthagyományozással, a hermeneutikát pedig az áthagyományozott dologgal kapcsolja össze: NiETzSCHE, Kritische Gesammelte Werke II., 3., 374 .
} 
inkább azé, amelyet Nietzsche nem feltétlenül ismert - vagy ha igen, kizárólag korán félbemaradt teológiai stúdiumaiból -, mégpedig a schleiermacheri hagyományé. Itt ugyanis a filológia alapvetően minőségi megközelítés: olyan tudomány, amely a kérdezőt magát is a folyamat aktív részesévé avatja - nem az objektív pozitivitás irányába mozdítva el a mindenkori értelmezést. A nietzschei legitimációs igény persze mindig a helyes tudat fellelését célozza meg, ami magában foglalja a kérdező és a kérdés kölcsönös egymásra vonatkozását, azaz amikor nem lesz eldönthető, hogy miről is folyik pontosan szó, hiszen egyszerre változik a kérdező és a kérdés is. A pozitív igény ebben a keretben meglepő eredményekhez vezet. A helyes kérdezés eladdig fel nem fedett összefüggésekre mutathat rá, amelyek nem hagyják érintetlenül az egész szituációt, amelyben a kérdés elhangzik: „Valójában az ember nem lehet filológus és orvos anélkül, hogy egyúttal ne lenne kereszténység-ellenes(Antikrisztus). Az ember ugyanis filológusként a »szent könyvek« mögé tekint, orvosként pedig a tipikus keresztény fiziológiai romlottság mögé. Az orvos azt mondja: »gyógyíthatatlan«, a filológus pedig azt, hogy: »szélhámosság«..."10 A megváltozott szituáció egészen új feltételeket teremt, melyeken belül nem kevesebb, mint maga az ön- és világértés formálódik át. Ebben rejlik egy filozófiaként művelt filológia veszélye...

A folytonosság és törés együtthatásának felmutatása után talán nem jogtalan az az állítás, hogy a nietzschei filozófia olyan filológián alapul, mely nemcsak a 19. század ókortudományában volt újszerű, de a jelen korok értelmezései számára is példaként szolgálhat. A tudományos megalapozást igénylő nietzschei filológia bázisát ugyanis olyan hermeneutika adja, mely minduntalan az önmegértésből és a szituatív-genealogikus kontextusból származtatja a helyes tudatot. A jelentés konstituálásában érdekelt, ez azonban nem csupán a textuális jelentés meghatározása kíván lenni. Ebből az összefüggésből ugyan éppenséggel a filológiai hermeneutika klasszikus előfeltevései hiányoznak (Nietzsche vizsgálódásai egyre kevésbé szövegközpontúak, noha sok esetben nyelvi elemzések); nem az áthagyományozott dolog belső jegyeinek feltárására irányul a figyelem, mégis azzal, hogy inkább a hagyományos kritika jellemzőivel szembesülünk, a filológiai kérdezésmódnak olyan általános megértésbeli vonásait fedezhetjük fel, mely új legitimációs környezetben - ki nem mondottan - a szellemtudományok kérdezésmódjává is válhat. Nietzsche eme filozófia és filológia között elfoglalt helye utat nyit e felé a lehetőség felé, ám nem teljesíti be azt. Ennélfogva igen termékeny lehetett különféle irányzatok számára, mivel filozófiája (mely tehát általános hermeneutikára alapozott filológia) épp a megismerés pozitivisztikus módszertanának ma is hasznosítható újrahangolására hívja fel a figyelmet.

Köznapi tapasztalat, hogy személyes élményeken keresztül tárul fel számunkra a tudáshoz vezető út. Egyetemi éveim kezdetén szigorú filológusok vezettek be

10 Friedrich Nietzsche, Az Antikrisztus, ford. Csejtei Dezső (h. n.: Ictus, 1993), 71-72. 
a szöveggondozás világába, amivel olyan alapokra igyekeztek rávezetni minket, melyek nélkül lehetetlen az irodalmi munka. Mindeközben pedig más mestereknek köszönhetően feltárult előttem az értelmezés olyan dimenziója is, melynek az olvasható szöveg képezte az alapját. E kettő olyan összefüggésbe helyezte magát az irodalmat, amely egyszerre megengedő volt az olvasat széles körű terjedésével szemben, de szigorú a tekintetben, hogy mennyire kell és lehet ragaszkodni a textualitás ajánlataihoz. A filológia elengedhetetlen ahhoz, hogy egyáltalán el tudjunk indulni az olvasás útján, de ha csak a szöveg maga marad a végállomás, akkor eltévesztettük célunkat. Sok olyan élő, formálódó kérdéssel ismerkedtünk meg a pesti bölcsészkar immár az idő ködébe veszett épületében és miliőjében, amely évtizedes berögzöttségű evidenciákat kérdőjelezett meg és helyezett hatályon kívül, miközben a szubverzív filológusok nem tagadták el annak izgalmát, ami a felfedezés és a felismerés közben a bírált nézetek átalakulását kísérte. Kritikai kiadások edíciója esetén, textológusok, szerkesztők munkájának megismerésekor a szöveg objektivitása a későbbiekben is egyszerre volt szilárd alap, mégis viták tárgya, és ennek intő jellege az interpretációra is kihatott. Mercurius és Philologia házassága felfedi azokat a fiktív elemeket, amelyek nem megdönthetetlen bizonyítékként, hanem izgalmas itinerként kísérik a szöveg megtapasztalását.

A filológiai gyakorlat detektívjellege ${ }^{11}$ megérzések és véletlenek heurisztikája révén kérdések, kudarcok és tévedések során igazolódik, miközben a tettes végérvényes és megkérdőjelezhetetlen lebuktatása a cél. A detektív persze csak odáig jut el, hogy az elkövetőt leleplezze (neve is ezt jelenti: vagy felfed, vagy a szálakat fejti fel, melyek a végkifejlethez [vagy a kezdeti tetthez] vezetnek), a bizonyítás jogi procedúrája a bíróság hatásköre. Ez a folyamat azonban csak perújrafelvételeknél kerül a krimik világába, mikor a nyomozó munkája (és kompetenciája) kérdőjeleződik meg. A filológiai tevékenység mindig ki van téve a perújrafelvétel lehetőségének, de leginkább a fiktív elemek érvényre jutása esetén válik botrányossá. A filológiai megközelítések sejtésekkel vagy kitalált elemekkel való „kivattázása” pedig elég ismert gyakorlat, nem lévén olyan bizonyíték az irodalomtörténetben, amely végérvényes hatállyal bírna. Elég ehelyütt csak Balassi Spenót-beli kötetkompozíciójának „igazolhatóságára” utalni... Amikor egy adatokkal nem igazán rendelkező nyomozást jelentek be, ezzel a fikciós igénnyel eleve szembesíteni igyekszem azokat, akik nem restek velem tartani, és nem félnek a grandiózus következtések elmaradásától és a szilárd eredmények helyett megfogalmazott kétségektől.

A felvilágosodás korának egy ismeretlen papjáról szeretnék megemlékezni. Bednanics Pál 1758-ban született, és 1817-ben hunyt el kalocsai kanokként. Neve egy lenne a sok közül a káptalani regiszterből, ha nem épp e sorok írójának családnevével volna azonos az övé, és ne volna egri irodalmi kötődése az egyházfinak.

11 Cerquiliglini, „A variáns dicsérete”, 267. 
A felvilágosodás korának gyermeke volt, bár odáig nem merészkedett, hogy nyomtatásban jelentesse meg állítólagos műveit. Épp ezért Szinnyei József gyűjtése nem vesz tudomást létezéséről. Alkotásai kéziratban maradhattak, az egri könyvtár azonban nem rögzítette ezeket a kéziratokat, ami persze nem jelenti azt, hogy ne lappanganának valahol (talán épp a könyvtárban), de persze az is lehetséges, hogy végleg elvesztek. A nagy irodalomszervező, Kazinczy nem ír róla, levelezésének jegyzeteiben van csak egy utalás rá, ${ }^{12}$ mint akire Moldoványi Antal (paptársa) emlékezett meg halálakor nekrológjában. Amit jelenleg Bednanics Pálról tudunk, ebből az írásos gesztusból tudjuk:

Fő tisztelendő Bednanics Pál, Kalocsai Kanonok, e’ folyó Esztendői Februárius 15-kén, szorgos életének 58-kában meghalálozott. Ezen érdemes Úr 1758-ban születvén, zsenge üdejétől fogva, szüntelen a' Musák baráttya volt. Különösen kedvelte a' Költő Mesterséget, mellynek próbáit sok alkalmatosságokkal kimutatta. Ô, mint nevendék Pap, a' Pesti, 's Egri Nevendék Házban Társaitól, mint Költő tiszteltetett. - Figyelmet okozott már akkor ama' Pásztori Dall, amelyet az akkorbéli Rector tiszteletére készitett,'s tapsolással eljátszatott. Elvégezvén tanúló pálya-futását, Káplányi, 's Plébániai szolgálattyában meg nem szűnt a' Musáknak koszorúkat füzni. De főképp a' Bácsi Plébániába,'s All-Öspörötségbe lett béiktatása után, majd minden nevezetes szomszéd baráttyai (kiket különösen szeretett, és viszont szerettetett, 's tiszteltetett: mint érzékeny ember,'s nemes lelkű Pap) történetei, 's ünneplései alkalmával, verseket énekelt deák, 's anya nyelven. Dücső példája másokat hasonlóra buzdított, hasznos következésekkel, kik őtet mint mesteröket példásan követgették. Különös dicséretére szolgál még az is, hogy Bácsi Plébániája Bunyeváczait (Katolikus Ráczok) meg nem szűnt magyarságra buzditani, méglen Ô Felségétől Kalocsai Kanonokságra érdemesnek itéltettvén, új tisztibe bé nem iktattatott; hol szintén szeretetre méltó nemes lelkűsége,'s példa nélkül lévő egyenes szivessége kitkit megbájólt. Halála minden érzékeny szivtől megsirattatott; hiv Barátin pedig keserű emlék billeget hagyott. Költeményei, 's más értekezései prés alá soha se jutottak (a' mennyire tudom), mellytől őtet dücsőséget éppen nem vadászó természete tiltotta el; csak Baráti közt folydogáltak azok. Igen jó volna, ha utolsó akarattya végbe vivői, Magyar’s Deák költeményeit kézirataiból kiszedegetve szeretett hazánkkal közleni nem terheltetnének. ${ }^{13}$

Ez a megemlékezés azonban beszédesebb, mint elsőre gondolnánk. Beszámol arról a korabeli állapotról, amelyben a fiatal, majd beérkezett papok fontosnak tartották

12 Kazinczy Ferenc levelezése, kiad. VÁczy János (Budapest: MTA, 1906), 15, 592.

13 MoldovÁNYI Antal, „Kihalt Tudósok és Irók”, Tudományos Gyújtemény 1, 5. sz. (1817), 142. 
irodalmi erudíciójukat, mégpedig azon a nyelven, amely a hivatalos diskurzuson kívül esett. A műfaj túlzásait is belekalkulálva nem tagadható el Bednanics Pál elkötelezettsége a literatúra iránt, amelynek szigorúan nem a köz, hanem a közeg számára volt érvénye: nyomtatásban nem, de kéziratokban, előadásokban fontosnak tartotta környezetével megosztani alkotásait. Kiemelkedő az, amikor a rektor tiszteletére adta elő idilljét, hiszen jeles alkalomra külön alkotott dalról van szó, melynek performanszát maga a szerző adta elő e visszaemlékezés szerint, mégpedig "tapsolással”, vagyis ritmizáló kísérettel. Hogy ez milyen nyelven történt, arról ez a nekrológ nem ad számot, de vélhetôleg latinul, a műfaj sajátosságainak megfelelően is. S bár a káptalani iratok, valamint a helytörténeti munkák rögzítik, hogy klerikális élete egészét délszláv nyelvi környezetben töltötte (tán azért, mert beszélte ezt a nyelvet), rácul született dalokról nem számol be paptársa. Latin és anyanyelvű versekről szól, és a bunyevác nyelvi közegben is a magyar identitás népszerűsítéséről számol be, ami arra enged következtetni, hogy e felvilágosult egyházfi a szórakoztatáson túl komoly missziót is megvalósított a magyar nyelv költői terjesztésével. Bács plébánosa 1803-ban lett, negyedikként a sorban, ${ }^{14}$ az aktív vallásos élet megindulását követő évtizedekben, tehát az akkor odavándorolt szláv ajkú népek számára újszerủ élmény lehetett, hogy egy, az övékhez hasonló hangzású névvel bíró egyházi elöljáró magyar nyelvű költeményekkel edukálja őket tizenegy esztendőn át. Ennek a nevelésnek nemcsak a szószékről elhangzó módon, de baráti környezetben is hangot adott, a nekrológ legalábbis ezt a hosszabb időszakot emeli ki klerikális tevékenységéből, se a korábbi, Szabadkán eltöltött időszakról (a ferencesek plébániáját kapja meg a város, mely számára új templomot építenek 1798-ban, így a szabadkai plébánosi sorban Bednanics Pál ugyan harmadik, de a templom első lelkésze), ${ }^{15}$ se a később, Kalocsán vállalt tisztségről nem ejt ilyen éllel szót Moldoványi. A szóban verselő poéta nem idegen persze korától, de ha le is hántjuk a nekrológszerző paptárs sallangjait, a múzsáknak mindvégig koszorúkat füző egyházfi irodalmi hatása közvetlen környezetére fontos helyi jelenségként pozicionálja Bednanicsot. A szóbeli kultúra melletti kitartás és a kéziratok elajándékozása/elveszejtése azt az átmeneti időszakot jelöli, amikor ha nem is az asztalfióknak írás, ám a dilettáns (vagyis nem professzionális) kísérletezés alkotóinak világával találkozunk.

Hogy szerzőnk miért is lehetett pesti és egri neveltetése után a kalocsai régió papja, arra pedig a hasonlóképp hézagos családtörténet kultúrhistoriográfiai körüljárása mutathat rá. A Bednanics család délről származott át, feltehetően a török veszedelem utáni idők migrációs időszakában. A Csepel-szigeten detektálható jelen korunkban is több família, akik e névvel rendelkeznek, egymást mégsem tekintik rokonnak. A budapesti telefonkönyv egyetlen ilyen családnevű egyént ismert évtizedekig (e sorok íróját is rajta keresték egyes évfolyamtársai a telefóniaínséges

14 BALOGH György, A bácsi r. k. plébánia százéves emléke (Esztergom: Horák Egyed, 1867), 28. 15 DudÁs Ödön, Szabadka város története (h. n. [Szabadka]: Életjel, 1991), 78. 
időkben). A Csepel-szigeti falusi hierarchiák kijelölik a család identitását: katolikus rácnak tekintik őket, vagyis délszláv nyelvűnek, de a szerbektől (rácok) megkülönböztetendőnek (más falu, más rítus, más temetkezési hely). Ez a származás kérdése okán lényeges, hiszen a déli részek származási differenciáit manapság nehéz szilárd kategóriákkal kijelölni. Mostanában a sokác kifejezéssel illetik ezt a népcsoportot, akik vélhetőleg Szlavónia térségéből jöttek Magyarországra - új magyar otthonukban a többi ráchoz képest máshonnan és tán vagy száz esztendővel később. Az 1700-as években már itt letelepedettként tarthatjuk őket számon, s bár Bednanics Pál születési helyét nem nevezik meg, akkor még túl nagy familiáris szóródás nem jellemezhette az e névvel élőket. A volt jugoszláv területek vezetéknév-nyilvántartásaiból arra lehet következtetni, hogy most se gyakori ez a jelölés, mintegy 90 ember viseli az ehhez hasonló Bednjanić nevet, többségében az Ivanec régióban, illetve Varasd környékén. Nagy valószínűséggel az a kisebb család, mely ideszármazott a török elvonulása után, adta a magyar kultúrának ezt a jeles papköltőt, kinek teljesítményéről semmiféle konkrét bizonyítékunk nincs, mert vagy túlságosan hitt a hangzó vers hagyományában, vagy nem is látta fontosnak, hogy műveit írásban rögzítse. Arra azonban gondot fordított, hogy nevelő és szórakoztató céllal egyaránt felhasználja azokat, s latin és magyar nyelven is e szándéknak megfelelően verseljen.

A filológia és a hermeneutika is számít a szövegre, hiszen annak megléte elengedhetetlen feltétele mind a textuális munkának, mind pedig az értelmezésnek. Ha nincs szöveg, elvileg nincs interpretáció sem. A fentiekben azonban egy filozófiatörténeti alapból kiindulva egy irodalomtörténeti példán keresztül igyekeztem láttatni, miképp is lehetséges mégis textus nélkül kontextusokat játékba hozni, felerősítve ezzel az antik mítosz üzenetét, hogy tudományunknak (mely az akkori értelemben művészet, és nem földi irányultságú) egyszerre van szüksége Philologiára és Hermészre, hogy releváns és hiteles módon bánjon az irodalommal. Van, amikor a szöveg a kontextusból lép elő, hiánya olyan nyom, amely utal ugyan nyomhagyójára, de nyomszerủ karakterét, körvonalait már nehezen detektáljuk. A senki által nem ismert, szem előtt nem tartott életművek felfedezései azonban a véletlenen múlnak. A fellelhető nyomokat igyekeztem rendszerezni, ebből a filológus detektívmunkájának megfelelően következtetéseket vontam le, óvatosan, hogy a bizonyíthatatlant azért ne mossam egybe az izgalmas fikció kiteljesítőképességével, ám a kéziratok hiányában ítéltet nem mondhattam a dicső pap irodalmi munkájáról vagy a kor kulturális terében betöltött szerepéről. Ha a véletlen előhozza a szövegeket, és ezzel átírja annak narratíváját, amit kibontani igyekeztem, akkor örömmel állok elébe, mert megtanultam azt is, a jó filológus nem ragaszkodik mereven a következtetéseihez, ha a szöveg iránti hűségét komolyan veszi, mert bármikor készen kell lennie az átírásra, a rekontextualizálásra, vagyis arra, hogy akár az egész munkáját sutba dobva új alapokra kell építkeznie. Az irodalom megújulásának, elevenségének ismérve ez, nemcsak sokféleképp lehet olvasni egy-egy szöveget, de sokféleképp is lehet újrarendezni a viszonyunkat hozzá. 
Mercurius és Philologia nászából az a Textus született meg, amely egyszerre pusztító szörnyeteg, mivel nem vagyunk képesek soha végérvényesen legyőzni, és egyszerre félisten, aki minden szépérzékkel és művészi nemességgel meg van áldva, mert épp a befogadás sokrétűségét és sokszínűségét teszi lehetővé.

\begin{abstract}
Marriage of Philologia and Mercurius was a satyrical poem of Martianus Capella that has several mythical messages to us. The connection of the god of eloquence and the mistress of the seven liberal arts points out that examining literature always has to reckon with both philological and hermeneutical issues. In my paper I deal with a concrete philological problem. Pal Bednanics, a poet and priest in the age of Enlightenment, did not pass any written poem to us, but tells a lot of our history. Philology is a state of understanding and an endeavour to express and contextualise informations gathered by textological work. Without text there are secondary texts that make us to build up contexts for literary and cultural history. These are traces we have to follow, even if we don't know their origin or authenticity.
\end{abstract}

